\title{
Original Paper / Artigo Original Synopsis of Cyperaceae in the grasslands of Guartelá State Park, Paraná, Brazil
}

\author{
Tainã de Souza ${ }^{1,3}$, Vanessa Liesenfeld ${ }^{1}$, Rafael Trevisan $^{2}$ \& Shirley Martins Silva ${ }^{1}$
}

\begin{abstract}
Cyperaceae is the third largest family among the monocotyledons and is highly represented in grassland environments. The aim of the present study was to conduct a floristic inventory of Cyperaceae in the grasslands of Guartelá State Park (GSP) and to elaborate keys to identify the species, the first for this family in this vegetation type in Paraná state. The GSP is home to relictual vegetation in Paraná, where grassland phytophysiognomies predominate, especially in open areas and rocky outcrops. The inventory was based on field collections and database searches. The family Cyperaceae is represented in the GSP by 32 taxa belonging to seven genera, with Rhynchospora (11 spp.), Bulbostylis (8 spp.), and Cyperus (7 spp.) being the genera with the greatest richness. It should be noted that all the species are native and two are endemic to Brazil. Species occurrence was recorded both in drylands and wetlands environments, emphasizing the importance of microenvironmental conservation in the park. The main literature sources for each genus, as well as information regarding distribution and habitat, are here provided.
\end{abstract}

Key words: Campos Gerais, floristics, grassland, Poales, taxonomy.

\begin{abstract}
Resumo
Cyperaceae é a terceira maior família dentre as monocotiledôneas, com grande representatividade em ambientes campestres. O presente estudo teve como objetivo realizar o levantamento florístico de Cyperaceae nas formações campestres do Parque Estadual do Guartelá (PEG) e elaborar chaves de identificação para as espécies, sendo o primeiro para a família nestes tipos de formações para o estado do Paraná. O PEG apresenta uma vegetação relictual do Paraná, onde predominam fisionomias campestres, destacando-se áreas abertas e afloramentos rochosos. O levantamento foi realizado com base em coletas em campo e buscas em banco de dados. A família Cyperaceae no PEG está representada por 32 táxons pertencentes a sete gêneros, sendo Rhynchospora (11 spp.), Bulbostylis (8 spp.) e Cyperus (7 spp.) os que apresentaram a maior riqueza. Ressaltase que todas as espécies são nativas, sendo duas endêmicas do Brasil. Registrou-se a ocorrência das espécies tanto em áreas drenadas quanto úmidas, destacando a importância da conservação dos microambientes do parque. São fornecidas principais literaturas para cada gênero, informações acerca da distribuição e habitat. Palavras-chave: Campos Gerais, florística, campos, Poales, taxonomia.
\end{abstract}

\section{Introduction}

Cyperaceae Juss. is distributed worldwide and is the third largest family, by number of species, among the monocotyledons, with 5,460 species (Govaerts et al. 2011) distributed in 106 genera (Govaerts et al. 2007). In Brazil, 673 species of Cyperaceae, distributed in 39 genera, have already been recorded (Alves et al. 2015; BFG 2018). However, specific taxonomic and floristic studies of this family are scarce and outdated (Ferreira \& Eggers 2008), making it difficult to identify certain groups of species in floristic studies of this family (Trevisan et al. 2008).

According to Govaerts et al. (2007), species of the family Cyperaceae occur mainly in wetlands (riverbanks, humid soils, and flooded areas), although some groups can also be found in drylands such as savannas, grasslands, rocky outcrops, and

\footnotetext{
${ }^{1}$ Universidade Estadual do Oeste do Paraná, Depto. Botânica, R. Universitária 2069, 85819-110, Jardim Universitário, Cascavel, PR, Brazil.

${ }^{2}$ Universidade Federal de Santa Catarina, Depto. Botânica, R. Roberto Sampaio Gonzaga s/n, 88040-900, Trindade, Florianópolis, SC, Brazil.

${ }^{3}$ Corresponding author: tainadsouzaa@gmail.com
} 
hilltops. The dominance of grass-like and other herbaceous species in these environments can be observed in the floristic composition of the Campos Gerais of Paraná (Labiak 2014), which is characterized as a natural phytogeographic unit formed of gallery forests, Mixed Ombrophilous forest fragments, grassland and relicts of the Cerrado (Maack 2012).

Among the general floristic inventories which mention Cyperaceae taxa in Paraná, in the Campos Gerais region, are Ferreira \& Maranho (2011), Oliveira \& Maranho (2011), Freitas et al. (2011), Oliveira et al. (2011), and Silva et al. (2016) in the Vila Velha State Park; Aguiar \& Vieira (2011) in the Cerrado State Park; Instituto Ambiental do Paraná (2002) and Carmo (2006) in the Guartelá State Park, being the only works which present data on Cyperaceae species, documenting 26 taxa, of which three were identified only to the generic level and five to the family level.

Taking into account that Guartelá State Park (GSP) presents a relictual vegetation for Paraná (Vasconcellos \& Rocha 2011) of great biological importance (Michelon \& Labiak 2013), this work constitutes the first floristic inventory of the family Cyperaceae in the grasslands of the GSP and also the first to elaborate dichotomous keys, providing new and important records of species and serving as a reference to recognize the species of this family in the park and in the Campos Gerais region of Paraná.

\section{Material and Methods}

The Guartelá State Park (GSP), which is located between the geographical coordinates $24^{\circ} 34^{\prime} 10.11^{\prime \prime} \mathrm{S}$ and $50^{\circ} 15^{\prime} 56.54^{\prime \prime} \mathrm{W}$, is part of the Environmental Protection Area of the Devonian Escarpment and it is inserted in the Campos Gerais region of the second plateau of Paraná, belonging to the municipality of Tibagi, Paraná (Instituto Ambiental do Paraná 2002; Carmo \& Assis 2012) (Fig. 1).

Considered one of the most important conservation units of the Campos Gerais region of Paraná, the GSP, covering an area of 798.97 hectares, presents one of the last original, native vegetation types of the state, where grassland phytophysiognomies (grassy-woody steppe, hygrophilous steppe, and rocky vegetational refuge), Mixed Ombrophilous forest, and Cerrado mosaic are predominant (Veloso et al. 1991; Instituto Ambiental do Paraná 2002; Vasconcellos \& Rocha 2011; Maia \& Goldenberg 2014).

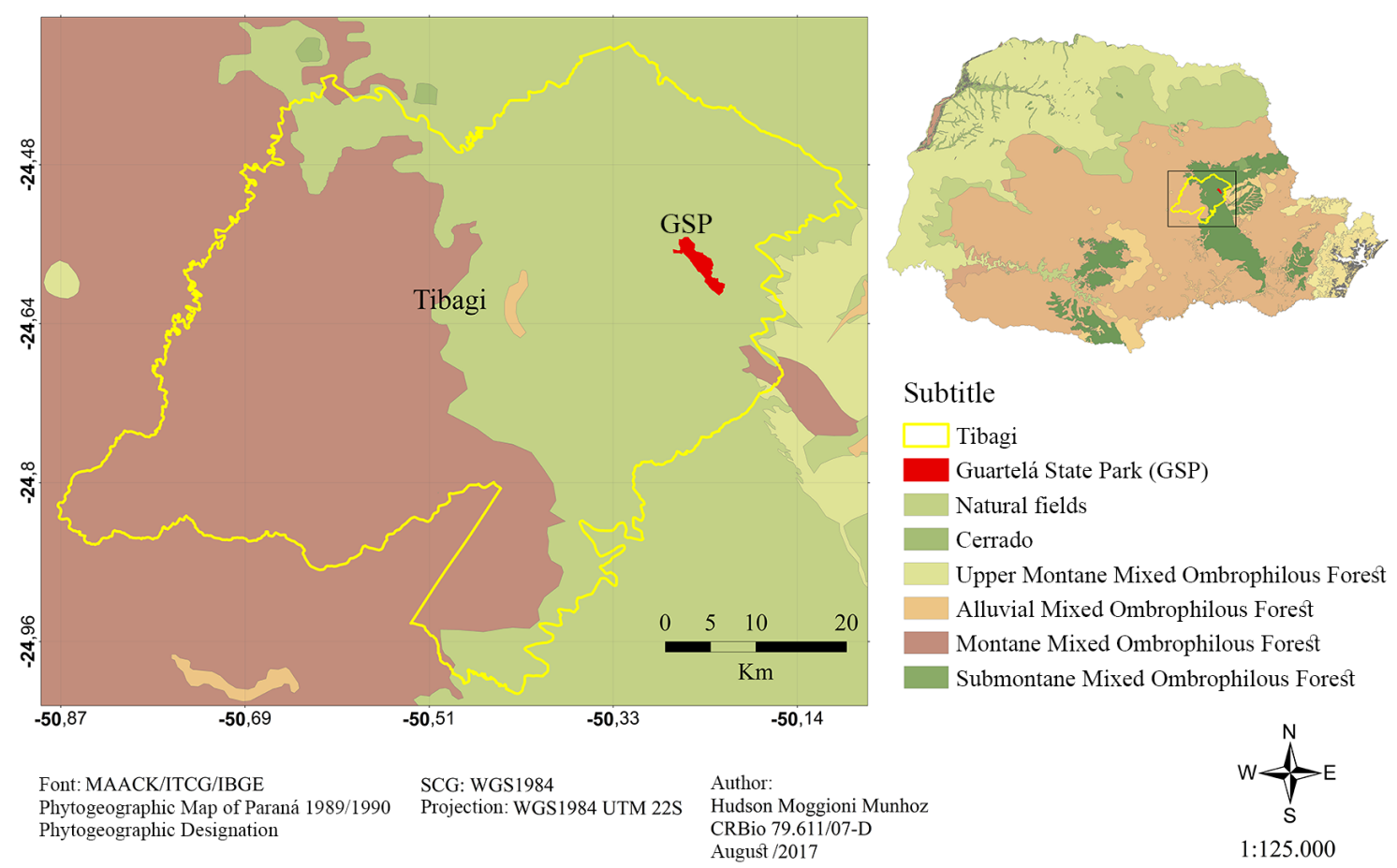

Figure 1 - Map of the region and vegetation where the Guartelá State Park, Tibagi, Paraná is located. 
The GSP region has a well-diversified relief, flat or gently undulated, with naturally poor shallow soils with low nutrient levels, water deficit, and high acidity, formed by the predominance of Cambisols and Lithosols derived from the sandstone deposition of furnas (Carmo et al. 2012; Instituto Ambiental do Paraná 2002) and rocky outcrops, which along with the grasslands account for $60.55 \%$ of the GSP area (Carmo 2006) (Fig. 2a-g). The climate is humid subtropical and influenced by the humid temperate climate, with well distributed rainfall over the year and a mean temperature of $18^{\circ} \mathrm{C}$ (Carmo 2006).

Fieldwork was carried in the months of March, June, August, and October 2015 and in January and April 2016, using the wide patrolling method described by Filgueiras et al. (1994). Aiming to sample all the grassland areas in the GSP (Fig. 2a-g), the following trails were explored: Básica (5,280 m long) and Pinturas Rupestres (7,500 $\mathrm{m}$ long), in addition to their surroundings.

All the collected specimens were herborized, following the techniques proposed by Bridson \& Forman (2004), and deposited in the UNOP herbarium of the State University of Western Paraná; duplicates were sent to the FLOR herbarium of the Federal University of Santa Catarina. The specimens were identified through comparison with the samples deposited in the herbarium of the Museu Botânico Municipal de Curitiba (MBM) and the ICN of the Universidade Federal do Rio Grande do Sul. We also used specific- and generic-level taxonomic studies in Cyperaceae.

In addition to the field expeditions, searches were carried out in the Species Link online database (http://inct.splink.org.br) in order to verify collection records of the family for the GSP, mainly for species not found by the authors in the field. The species indicated were confirmed through visits to the FLOR and ICN herbaria and soon afterward were included in the keys. These are referenced as additional material next to the material examined.

The achene dimensions cited in the keys include the stylopodium, when present. We present keys for the genus and species within each genus. The species which are the sole representatives of their genus are cited directly in the generic-level key. For the species, information on the distribution, habitat, material examined, and complementary bibliographic references of the family is added.

The images of the achenes and glumes were captured, by Tainã Souza, through an SC30 camera coupled to an Olympus SZX7 stereomicroscope.
Some images were obtained from materials collected in other places, by Rafael Trevisan, which are mentioned in the item "material examined".

\section{Results and Discussion}

We found 32 taxa of Cyperaceae in Guartelá State Park, belonging to the genera Bulbostylis Kunth, Cyperus L., Eleocharis R.Br., Fimbristylis Vahl, Lagenocarpus Nees, Rhynchospora Vahl, and Scleria P. J. Bergius.

The genera with the highest number of taxa were Rhynchospora (11 spp.), Bulbostylis (8 spp.), Cyperus (7 spp.), Fimbristylis (2 spp.), and Scleria (2 spp.), while Eleocharis and Lagenocarpus presented only one species each.

Most of the Cyperaceae species in the grasslands of the GSP, mainly those belonging to Bulbostylis, Lagenocarpus and Rhynchospora, were found in grasslands with drained, sandy soil and in rocky outcrops (Fig. 2a,d,g), corroborating with the indications of the environment of occurrence for species of these genera (Prata 2004; Vitta 2005; Araújo et al. 2012; Ardissone 2013; Weber 2014). Many species of Cyperus and Fimbristylis found are considered ruderal or even weedy (Lorenzi 2014; Ronchi 2015), and their presence can be explained by the proximity of the trails to anthropized areas and crop fields (Araújo \& Longhi-Wagner 1996; Ardissone 2013; Martins et al. 2015). The other monospecific genera, Eleocharis and Scleria, were observed in wet, sandy soils and near bodies of water (Fig. 2b-c) (Muniz \& Shepherd 1987; Trevisan \& Boldrini 2008).

It was observed that most species studied have been registered in other countries and in almost all Brazilian regions. However, $R$. edwalliana, Bulbostylis jacobinae and $B$. sp. nov. 3 (Prata 2004) are considered endemic to Brazil (BFG 2018). Rhynchospora pungens and B. sp. nov. 3 (Prata 2004) have restricted distributions in the Southeast and South of Brazil.

Some species, such as Bulbostylis hirtella, Rhynchospora albiceps Kunth, $R$. brasiliensis, $R$. consanguinea (Kunth) Boeckeler, R. junciformis (Kunth) Boeckeler, $R$. pungens, $R$. velutina, Scleria distans, and S. leptostachya, were not found during the field expeditions, although there have been collection records of these species in the GSP for over last 12 years. Possibly, it was due to the flowering time of the species, which did not coincide with the collection dates, or because these species might no longer occur in this site. 

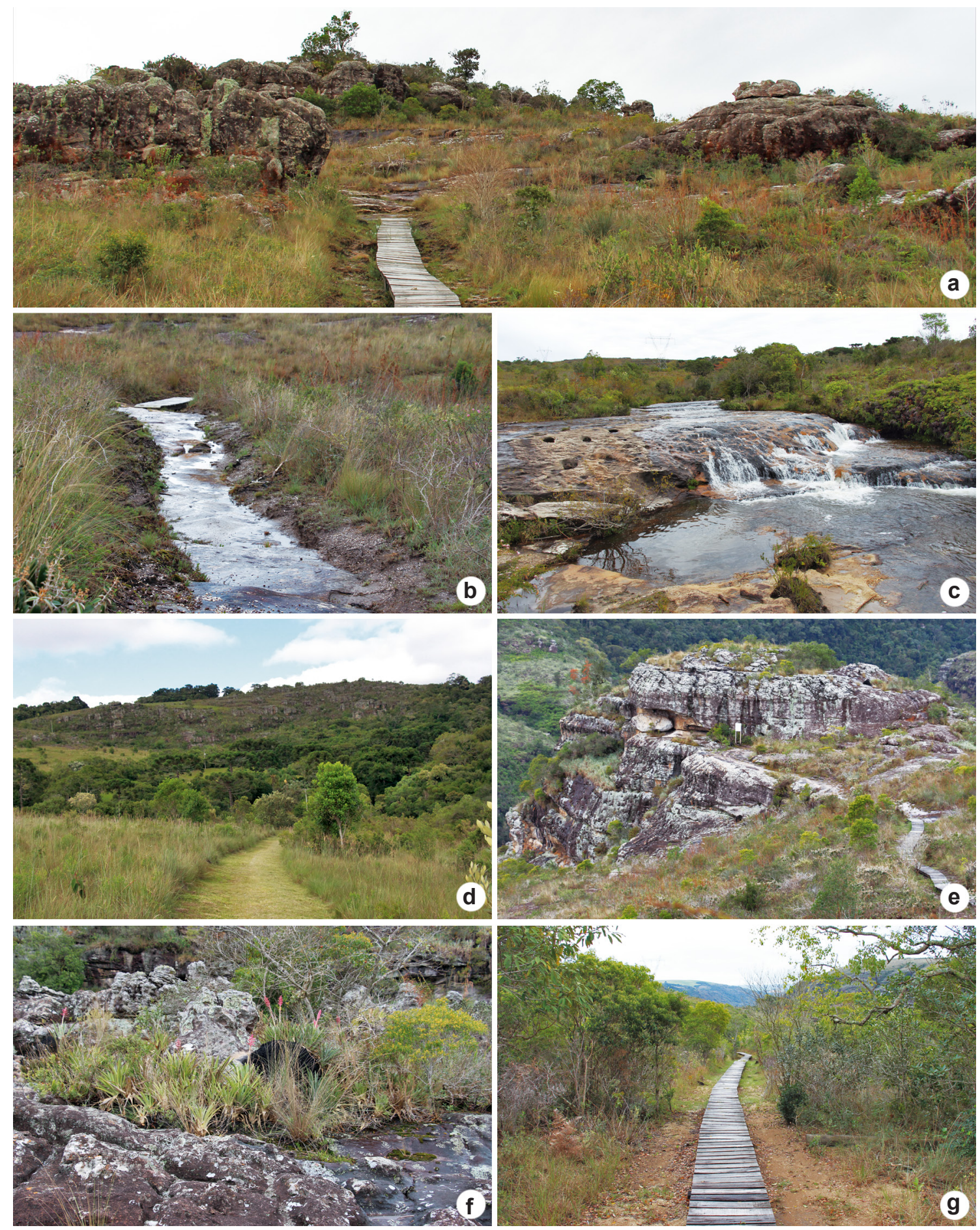

Figure 2 - a-g. Open-area environments in the Guartelá State Park, Paraná - a. rocky outcrop; b. wet sandy soil; c. flooded areas; d. drained, sandy soil; e. rocky outcrop; f. rocky outcrop; g. drained, sandy soil. 
Among the species mentioned above, Bulbostylis hirtella, Rhynchospora pungens, $R$. velutina, Scleria distans and S. leptostachya were included in the keys of the present study after confirming the identification of the specimens deposited in the FLOR and ICN herbaria, while the other species (Rhynchospora albiceps, $R$. consanguinea and $R$. junciformis) were not included due to the difficulty of precise confirmation of identification of these species. According to Araújo (2001), $R$. albiceps and $R$. consanguinea are very similar morphologically and occur sympatrically. In the case of R. junciformis, Michelan et al. (2012) found, in addition to morphological similarity, the species also overlaps in cytogenetic characters and molecular markers with $R$. tenuis, a species found in this work.

With the obtained data, it was possible to increase the number of Cyperaceae species previously indicated for the GSP (Instituto Ambiental do Paraná 2002; Carmo 2006) from 26 to 32 , which makes this family one of the most representative families in the herbaceous component of the grasslands of the park. It should be noted that all species are native; some are endemic to Brazil and common for the environmental types found in the GSP, equally in wet areas as in drained ones. These results highlight the importance of microenvironmental conservation, which can be affected by the tourist trails in the park.

\section{Key to the Genera of Cyperaceae occurring in Guartelá State Park - PR}

1. Single spikelet at the apex of the floriferous culm 3.1. Eleocharis maculosa

1'. Spikelets gathered in different types of inflorescence, never a single spikelet at the apex of the floriferous culm.

2. Spikelets composed of unisexual flowers.

3. Inflorescence in a lax panicle with pistillate spikelets at the apical portion and staminate at the proximal portion 5.1. Lagenocarpus rigidus

3'. Inflorescence in a simple or compound, fasciculate spike with spikelets grouped in fascicules along the axis 7. Scleria

2'. Spikelets composed of only bisexual flowers or at least with one bisexual flower in each spikelet.

4. Glumes distically arranged; style base not inflated 2. Cyperus

4'. Glumes spirally arranged; style base inflated, forming a deciduous or persistent stylopodium. 5. Style undivided or bifid; achenes biconvex.

6. Ligule absent; stylopodium persistent at the apex of the mature achene

6'. Ligule present; stylopodium always deciduous in the mature achene 6. Rhynchospora 4. Fimbristylis

5'. Style trifid; achenes trigonous.

7. Leaves with sheath apex glabrous or with very short trichomes; ligule present; stylopodium deciduous 4. Fimbristylis

7'. Leaves usually with long hairs at the sheath apex; ligule absent; stylopodium persistent, tubercle-shaped 1. Bulbostylis

1. Bulbostylis Kunth, Enum. P1. 2: 205 (1837), nom. cons.
Main references: Prata (2004) and Ardissone (2013).

\section{Key to the species of Bulbostylis from Guartelá State Park}

1. Inflorescence capitate.

2. Base of the plant woolly, shredded remains of old sheath persistent. Inflorescence of up to 7 spikelets 1.6. Bulbostylis sellowiana

2'. Base of the plant glabrous or with short trichomes, never woolly, old sheath not persistent at base. Inflorescence of 10-many spikelets. 
3. Glumes recurved-mucronate. Achene $0.7-0.9 \mathrm{~mm}$ long 1.5. Bulbostylis junciformis

3'. Glumes straight-mucronate. Achene $\geq 1.1 \mathrm{~mm}$ long 1.7. Bulbostylis sphaerocephala 1'. Inflorescence anthelate.

4. Inflorescence arranged in an anthelodium of fascicles or capitula ... 1.5. Bulbostylis junciformis

4'. Inflorescence in a simple or compound anthelodium of isolated or binate spikelets.

5. Leaf blade $<6 \mathrm{~mm}$ 1.1. Bulbostylis brevifolia

5'. Leaf blade longer than $35 \mathrm{~mm}$.

6. Plants with leaves and culms covered in straight trichomes .... 1.3. Bulbostylis hirtella 6'. Plants glabrous or scabrous, never covered in straight trichomes.

7. Leaves flat, $1.7 \mathrm{~mm}$ wide 1.4. Bulbostylis jacobinae

7'. Leaves filiform-convolute, $0.2-0.9 \mathrm{~mm}$ wide.

8. Spikelet $2.2-3 \times 1 \mathrm{~mm}$. Achenes $1 \times 0.6 \mathrm{~mm} \ldots . . .1 .2$. Bulbostylis capillaris

8'. Spikelet $4.5-5 \times 2 \mathrm{~mm}$. Achenes $1.2 \times 0.7-0.8 \mathrm{~mm}$

1.8. Bulbostylis sp. nov. 3 (Prata 2004)

1.1 Bulbostylis brevifolia Palla, Denkschr. Kaiserl. Akad. Wiss., Wien. Math.-Naturwiss. K1. 79: 178 (1908).

Fig. 3a

Distribution: Argentina, Paraguay, Uruguay and in Brazil the species occurs in the Northeast, Central-West, Southeast and South regions (Prata 2004; Alves et al. 2009; Ardissone 2013). Found in drained, sandy soil.

Material examined: 26.III.2015, fl. and fr., V. Liesenfeld et al. 29 (UNOP); 2.VI.2015, fl. and fr., V. Liesenfeld et al. 37 (UNOP); 26.VIII.2015, fl. and fr., V. Liesenfeld et al. 57 (UNOP).

1.2 Bulbostylis capillaris (L.) Kunth ex C.B.Clarke in J.D.Hooker, Fl. Brit. India 6: 652 (1893).

Fig. $3 b$

Distribution: American tropics and subtropics. In Brazil, it occurs in the Northeast, Central-West, Southeast and South regions (López \& Simpson 2012). Found in drained, sandy soil.

Material examined: 26.III.2015, fl., V. Liesenfeld et al. 01 (UNOP).

1.3 Bulbostylis hirtella (Schrad.) Nees ex Urb., Symb. Antill. 2: 166 (1900). Fig. 3c

Distribution: from Mexico to northern Argentina. In Brazil, it occurs in the North, Northeast, CentralWest, Southeast and South regions (Prata 2004; Alves et al. 2009; Ardissone 2013). Found in damp fields.

Material examined: Tibagi, Guartelá State Park, 26.I.1997, fl. and fr., H.M. Longhi-Wagner 3827 (ICN).

1.4 Bulbostylis jacobinae (Steud.) Lindm., Bih. Kongl. Svenska Vetensk.-Akad. Handl. 26(9): 18 (1900).

Fig. 3d-e

Distribution: Endemic to Brazil, occurring in the North, Northeast, Central-West, Southeast and South regions (Prata 2004; Alves et al. 2009; Ardissone 2013). Found in drained, sandy soil. Material examined: 26.VIII.2015, fl., V. Liesenfeld et al. 58 (UNOP); 26.X.2015, fl., V. Liesenfeld et al. 62 (UNOP).

1.5 Bulbostylis junciformis (Kunth) C.B.Clarke, Trans. Linn. Soc. London, Bot. 4: 512 (1895).

Fig. 3f-g

Distribution: From Mexico to Uruguay. In Brazil, it occurs in the North, Northeast, Central-West, Southeast and South regions (Prata 2004; Alves et al. 2009; Ardissone 2013). Found in rocky outcrops and drained, sandy soil.

Material examined: 2.VI.2015, fl. and fr., V. Liesenfeld et al. 33 (UNOP).

1.6 Bulbostylis sellowiana (Kunth) Palla, Denkschr. Kaiserl. Akad. Wiss., Wien. Math.-Naturwiss. Kl. 79: 179 (1908).

Fig. 3h-i

Distribution: Paraguay and in Brazil occurring in the Northeast, Central-West, Southeast and South regions (Prata 2004; Alves et al. 2009; Ardissone 2013). Found in wet, sandy soil.

Material examined: 2.VI.2015, fl. and V. Liesenfeld et al. 48 (UNOP).

1.7 Bulbostylis sphaerocephala (Boeckeler) Lindm., Bih. Kongl. Svenska Vetensk.-Akad. Handl. 26(9): 18 (1900).

Fig. $3 \mathrm{j}-\mathrm{k}$

Distribution: Argentina, Paraguay, Bolivia and in Brazil occurring in the Northeast, Central-West, Southeast and South regions (Prata 2004; Alves et al. 2009; Ardissone 2013). Found in rocky outcrops, drained and wet, sandy soil.

Material examined: 26.III.2015, fl. and fr., V. Liesenfeld et al. 16 (UNOP); 2.VI.2015, fl. and fr., $V$. Liesenfeld et al. 34, 35, 36 (UNOP); 26.VIII.2015, fl. and fr., $V$. Liesenfeld et al. 55 (UNOP). 

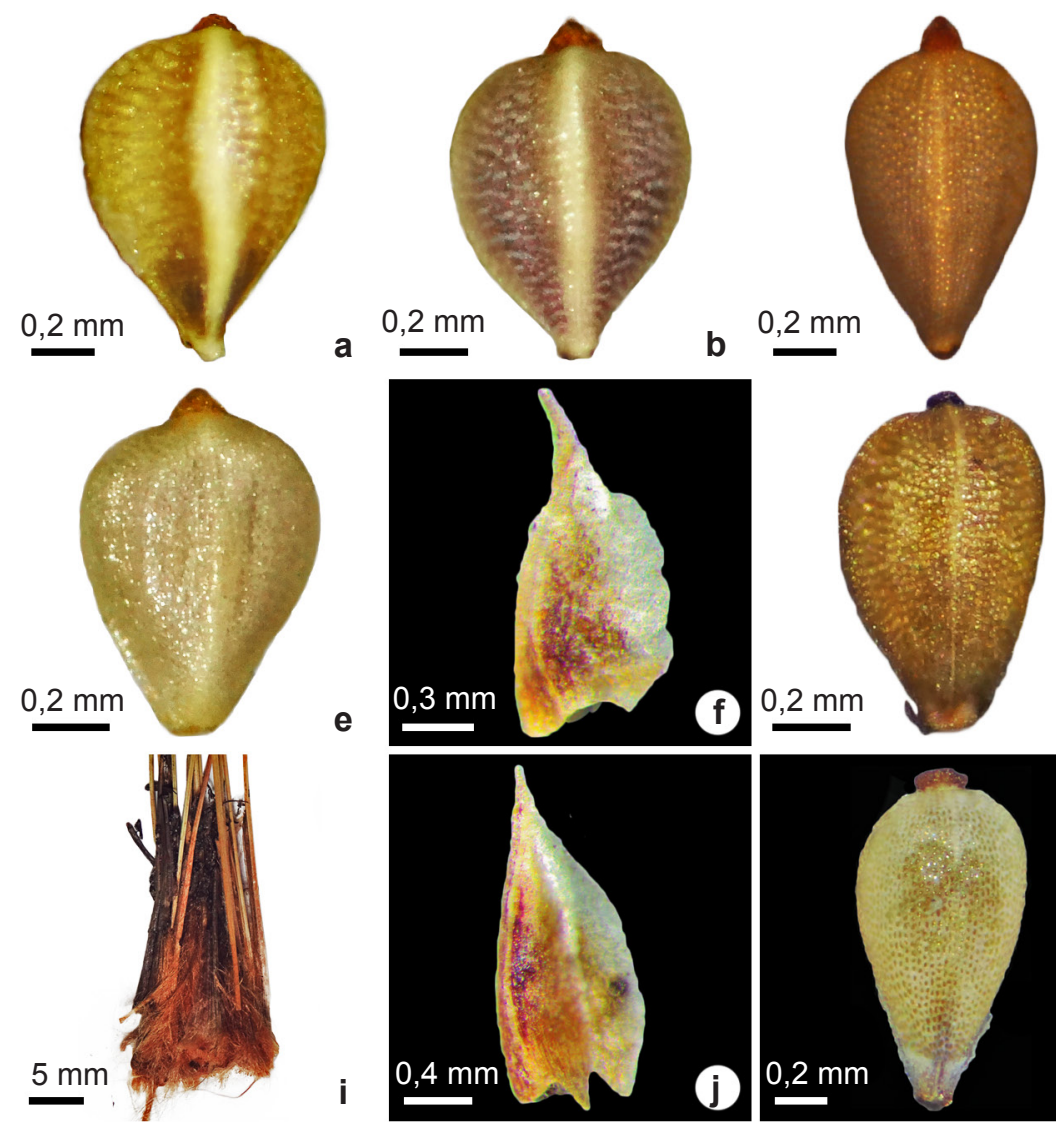

c $1 \mathrm{~cm}$
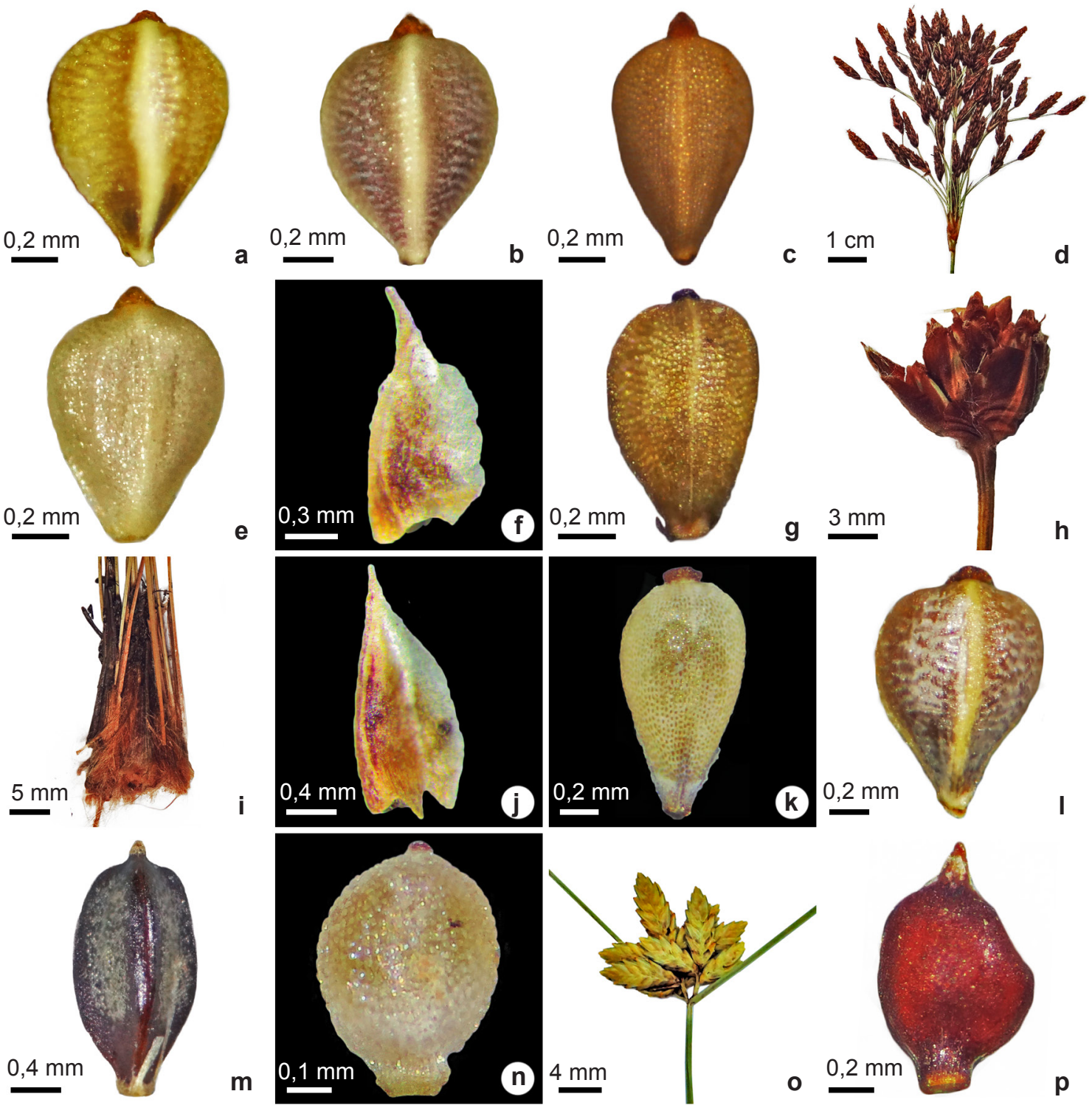

$\mathbf{h}$
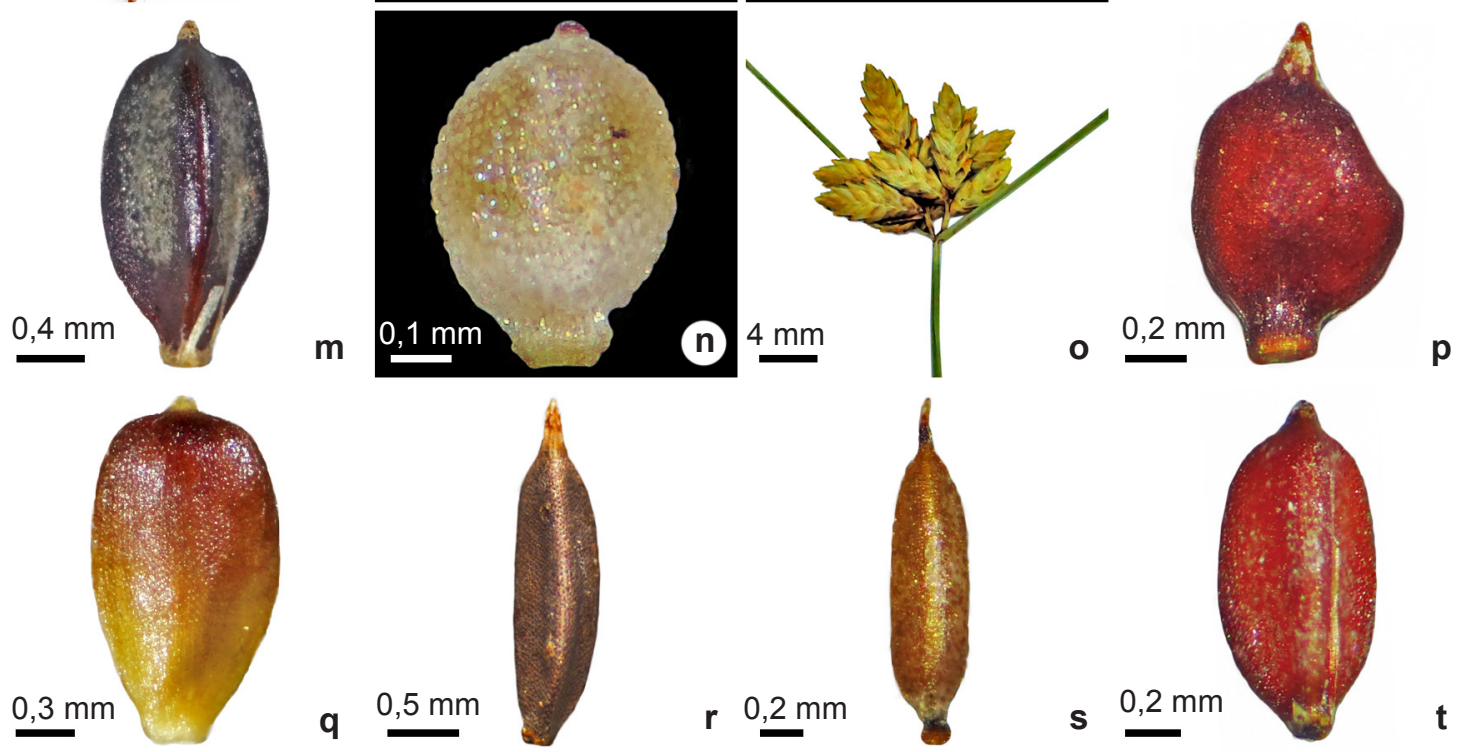

Figure 3 - Bulbostylis brevifolia - a. achene. B. capillaris - b. achene. B. hirtella - c. achene. d-e. B. jacobinae $-\mathrm{d}$. inflorescence; e. achene. f-g. $B$. junciformis $-\mathrm{f}$. glume in lateral view, highlighting the recurved-mucronate tip; g. achene. h-i. B. sellowiana - h. inflorescence; i. plant base. j-k. B. sphaerocephala -j. glume in lateral view, highlighting the straight mucronate tip; k. achene. B. sp. nov. $3-1$. achene. Cyperus aggregatus $-\mathrm{m}$. achene. $C$. haspan - n. achene. o-p. C. lanceolatus - o. inflorescence; p. achene. C. sesquiflorus - q. achene. C. prolixus - r. achene. C. reflexus var. fraternus $-\mathrm{s}$. achene. C. rigens var. rigens - t. achene. 
1.8 Bulbostylis sp.

Fig. 31

Distribution: In Brazil, it occurs in the Southeast and South regions (Prata 2004). Found in drained, sandy soil. The morphological characteristics of this specimen are similar to those described by Prata (2004) as a possible new species (Bulbostylis sp. 3).
Material examined: 26.III.2015, fl. and fr., V. Liesenfeld et al. 08 (UNOP).

2. Cyperus L., Sp. Pl.: 44 (1753).

Main references: Adams (1994a), Araújo \& Longhi-Wagner (1996) and Hefler \& LonghiWagner (2012).

\section{Key to the species of Cyperus from Guartelá State Park}

1. Style bifid; achenes laterally compressed.

2. Spikelets pluri-flowered, united in fascicles, glomerules or spikes, when spicate, it is pedunculate ...

2'. Spikelets 1-2 flowered united in one to three sessile spikes 2.3. Cyperus lanceolatus 2.4. Cyperus sesquiflorus

1'. Style trifid; achenes trigonous.

3. Partial inflorescence digitate or in glomerules, never in spikes.

4. Plants with reduced leaf blades, inflorescence in compound anthelodium; achenes widely elliptical, $0.4-0.6 \mathrm{~mm}$ long 2.2. Cyperus haspan

4'. Plants with developed leaf blades, inflorescence in simple anthelodium; achenes narrowly elliptical, $0.9-1.7 \mathrm{~mm}$ long 2.6. Cyperus reflexus var. fraternus

3'. Partial inflorescence in dense or lax spikes.

5. Inflorescence congested at the apex of the floriferous culm; spikelets gathered in sessile spikes; glumes green 2.1. Cyperus aggregatus

5'. Inflorescence in simple or compound anthelodium; spikelets united in spikes located at the apex of the lateral branches; glumes straw-colored.

6. Inflorescence in lax anthelodium with long and pendant branches; spikes cylindrical; spikelets ascending 2.5. Cyperus prolixus

6'. Inflorescence in contracted anthelodium with rigid branches; spikes obovoid to globose; spikelets patent 2.7. Cyperus rigens var. rigens

2.1 Cyperus aggregatus (Willd.) Endl., Cat. Horti Vindob. 1: 93 (1842). Fig. $3 \mathrm{~m}$

Distribution: From North to South America (Adams 1994a). In Brazil, it occurs in the North, Northeast, Central-West, Southeast and South regions (Alves et al. 2009). Found in drained, sandy soil.

Material examined: 21.I.2016, f1., V. Liesenfeld et al. 84 (UNOP).

2.2 Cyperus haspan L., Sp. P1.: 45 (1753).

Fig. 3n

Distribution: Tropics and subtropics (Araújo \& Longhi-Wagner 1996). In Brazil, it occurs in the North, Northeast, Central-West, Southeast and South regions (Alves et al. 2009). Found in rocky outcrops, near water.

Material examined: 26.III.2015, fl., $V$. Liesenfeld et al. 13 (UNOP).

Additional material examined: BRAZIL. SANTA CATARINA: Florianópolis, Av. Virgílio C., Saco Grande,
Ilha de Santa Catarina, 6.II.1985, fl. and fr., M.Y.L. Meruvia 7288 (FLOR).

2.3 Cyperus lanceolatus Poir. in J.B.A.M.de Lamarck, Encycl. 7: 245 (1806). Fig. 3o-p

Distribution: From North to South America (Tucker 1994). In Brazil, it occurs in the North, Northeast, Central-West, Southeast and South regions (Alves et al. 2009). Found in wet, sandy soil. Material examined: 21.I.2016, fl., V. Liesenfeld et al. 80 (UNOP).

2.4 Cyperus sesquiflorus (Torr.) Mattf. \& Kük. in H.G.A.Engler (ed.), Pflanzenr., IV, 20(101): 19 (1935).

Fig. 3q

Distribution: From North to South America (Adams 1994a). In Brazil, it occurs in the North, Northeast, Central-West, Southeast and South regions (Alves et al. 2009). Found in drained, sandy soil.

Material examined: 26.X.2015, fl., V. Liesenfeld et al. 85 (UNOP). 
2.5 Cyperus prolixus Kunth in F.W.H.von Humboldt, A.J.A.Bonpland \& C.S.Kunth, Nov. Gen. Sp. 1: 206 (1816).

Fig. 3r

Distribution: From North to South America (Adams 1994a). In Brazil, it occurs in the North, Northeast, Central-West, Southeast and South regions (Barros 1960; Alves et al. 2009). Found in wet, sandy soil.

Material examined: 21.I.2016, fl., V. Liesenfeld et al. 78 (UNOP).

2.6 Cyperus reflexus var. fraternus (Kunth) Kuntze, Revis. Gen. Pl. 3(2): 334 (1898). Fig. 3s Distribution: North, Central and South America. In Brazil, it occurs in the Central-West, Southeast and South regions (Araújo \& Longhi-Wagner 1996; Alves et al. 2009). Found in wet, sandy soil. Material examined: 26.X.2015, fl. and fr., V. Liesenfeld et al. 69 (UNOP).

2.7 Cyperus rigens var. rigens J.Presl \& C.Presl, Reliq. Haenk. 1: 170 (1828). Fig. 3t

Distribution: Brazil, Paraguay and Eastern Argentina (Pedersen 1972). In Brazil, it occurs in the North, Northeast, Central-West, Southeast and
South regions (Alves et al. 2009). Found in wet, sandy soil.

Material examined: 26.III.2015, fl. and fr., V. Liesenfeld et al. 09, 27 (UNOP).

3. Eleocharis R.Br., Prodr. Fl. Nov. Holland.: 224 (1810).

Main references: Gil \& Bove (2004) and Trevisan \& Boldrini (2008).

3.1 Eleocharis maculosa (Vahl) Roem. \& Schult., Syst. Veg., ed. 15 bis 2: 154 (1817). $\quad$ Fig. 4a-b Distribution: Central and South America. In Brazil, it occurs in the North, Northeast, CentralWest, Southeast and South regions (Trevisan \& Boldrini 2008; Alves et al. 2009). Found in wet, sandy soil.

Material examined: 26.III.2015, fl. and fr., V. Liesenfeld et al. 20 (UNOP); 21.I.2016, fl. and fr., V. Liesenfeld et al. 81 (UNOP).

4. Fimbristylis Vahl, Enum. Pl. Obs. 2: 285 (1805), nom. cons.

Main references: Adams (1994b) and Ronchi (2015).

\section{Key to the species of Fimbristylis from Guartelá State Park}

1. Spikelet lanceolate; achene trigonous, smooth to finely reticulate; style trifid, not fimbriate 4.1. Fimbristylis complanata

1'. Spikelet ovoid to ellipsoid; achene biconvex, strongly latticed with surface composed of 7-11 vertical series of cells; style bifid, fimbriate 4.2. Fimbristylis dichotoma

4.1 Fimbristylis complanata (Retz.) Link, Hort. Berol. 1: 292 (1827).

Fig. 4c

Distribution: Pantropical (Adams 1994b). In Brazil, it occurs in the North, Northeast, Central-West, Southeast and South regions (Alves et al. 2009). Found in wet, sandy soil and near water.

Material examined: 26.III.2015, fl. and fr., V. Liesenfeld et al. 14 (UNOP); 21.I.2016, fl. and fr., V. Liesenfeld et al. 82,83 (UNOP).

4.2 Fimbristylis dichotoma (L.) Vahl, Enum. Pl. Obs. 2: 287 (1805).

Fig. 4d

Distribution: Tropical and subtropical (Adams 1994b) regions. In Brazil, it occurs in the North, Northeast, Central-West, Southeast and South regions (Alves et al. 2009). Found in wet, sandy soil.

Material examined: 26.III.2015, fl. and fr., V. Liesenfeld et al. 03 (UNOP).
5. Lagenocarpus Nees, Linnaea 9: 304 (1834). Main references: Adams (1994c) and Vitta (2005).

5.1 Lagenocarpus rigidus (Kunth) Nees in C.F.P.von Martius \& auct. suc. (eds.), Fl. bras. 2(1): 167 (1842).

Fig. 4e-f

Distribution: Tropical and subtropical (Adams 1994c) regions. In Brazil, it occurs in the North, Northeast, Central-West, Southeast and South regions (Alves et al. 2009). Found in rocky outcrops. Material examined: 26.III.2015, fl. and fr., V. Liesenfeld et al. 06 (UNOP); 26.X.2015, fl. and fr., V. Liesenfeld et al. 87 (UNOP).

6. Rhynchospora Vahl, Enum. Pl. Obs. 2: 229 (1805), nom. cons.

Main references: Barros (1960), Koyama (1972), Guaglianone (1980, 1981, 1982, 2001), Guaglianone \& Moore (2001), Rocha \& Luceño (2002), Araújo et al. (2012) and Weber (2014). 

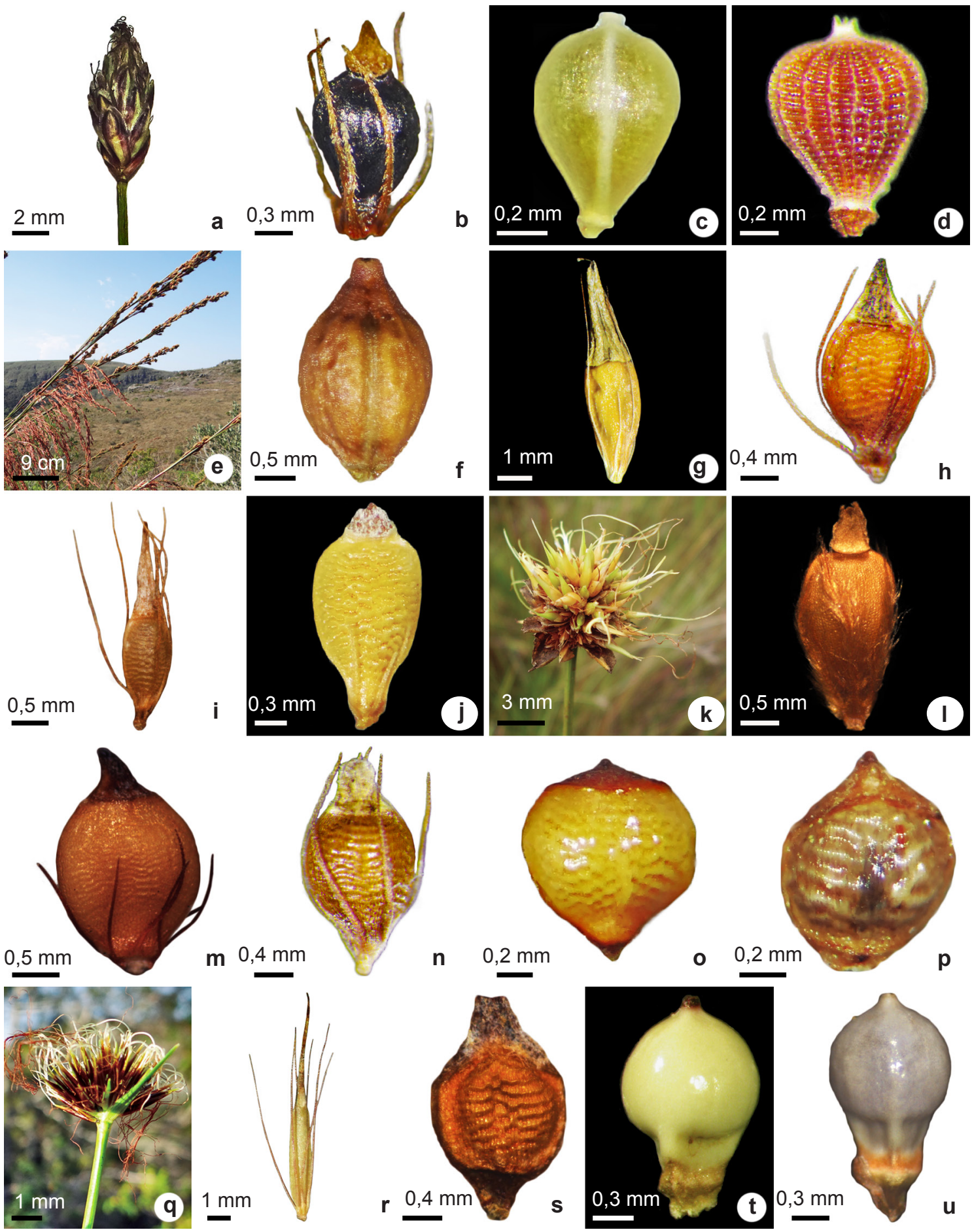

Figure 4 - a-b. Eleocharis maculosa - a. spikelet; b. achene. Fimbristylis complanata - c. achene. F. dichotoma - d. achene. e-f. Lagenocarpus rigidus - e. inflorescence; f. achene. Rhynchospora asperula - g. achene. R. barrosiana - h. achene. R. brasiliensis - i. achene. R. edwalliana - j. achene. k-1. R. globosa - k. inflorescence; 1 . achene. $R$. pungens $-\mathrm{m}$. achene. R. rugosa - n. achene. R. setigera - o. achene. R. tenuis - p. achene. q-r. R. terminalis var. terminalis - q. inflorescence; r. achene. R. velutina - s. achene. Scleria distans - t. achene. S. leptostachya - u. achene. 


\section{Key to the species of Rhynchospora from Guartelá State Park}

1. Spikelet sessile, grouped in one or more dense glomerules.

2. Plants with old sheaths shredded into fibers at the base; culm apex with a single whitish (creamcolored) glomerule; style undivided or shortly bifid at the apex; hypogynous bristles absent ...... 6.8. Rhynchospora setigera

2'. Plants with old sheath not shredded into fibers at the base; culm apex with a single, ferrugineous to dark brown glomerule; style longly bifid (more than half of the style); hypogynous bristles $p$. resent.

3. Involucral bracts leaf-like, green, at least twice longer than the glomerule; achene oblong . 6.10. Rhynchospora terminalis var. terminalis

3'. Involucral bracts squamiform, orange castaneous or black, equal or shorter than the glomerule; achene obovoid 6.5. Rhynchospora globosa

1'. Spikelet pedicellate, grouped in fascicles, never grouped in dense glomerules.

4. Hypogynous bristles absent.

5. Spikelets 3-3.5 × 0.5-0.9 mm; achene $0.7-0.9 \mathrm{~mm}$ long 6.9. Rhynchospora tenuis

5. Spikelets $7-8 \times 1.5-2.5 \mathrm{~mm}$; achene $1.5-2.2 \mathrm{~mm}$ long 6.11. Rhynchospora velutina

4'. Hypogynous bristles present (sometimes rudimentary in R. edwalliana, if rudimentary then inflorescence terminal with 3-9 spikelets).

6. Style undivided or shortly bifid at the apex; stylopodium conic to pyramidal $2.4-4.5 \mathrm{~mm}$ long, as long or longer than the achene's body; leaves $6-10 \mathrm{~mm}$ wide

6.1. Rhynchospora asperula

6'. Style longly bifid (more than half of the style), stylopodium hemispheric, deltoid or triangular, 0.3-1.7 mm long, shorter than the achene's body; leaves $0.2-5 \mathrm{~mm}$ wide.

7. Leaves filiform, $0.2-0.5 \mathrm{~mm}$ wide; spikelets $1.2-1.8 \mathrm{~mm}$ long 6.4. Rhynchospora edwalliana

7'. Leaves flat, $1-5 \mathrm{~mm}$ wide; spikelets $2.2-5.5 \mathrm{~mm}$ long.

8. Achene linear-oblong to narrow-ellipsoid, up to $0.8 \mathrm{~mm}$ wide 6.3. Rhynchospora brasiliensis

8'. Achene obovoid, wide-ellipsoid to suborbicular, more than $0.8 \mathrm{~mm}$ wide.

9. Achene slightly rugose, almost smooth; hypogynous bristles usually shorter than the apex of the achene's body 6.6. Rhynchospora pungens

9'. Achene with 9-12 conspicuous transversal wrinkles; hypogynous bristles as long as the achene or surpassing the stylopodium.

10. Furrow between the achene's body and the stylopodium base present; hypogynous bristles as long as the achene

6.2. Rhynchospora barrosiana

10'. Furrow between the achene's body and the stylopodium base absent; hypogynous bristles surpassing the stylopodium

6.7. Rhynchospora rugosa

6.1 Rhynchospora asperula (Nees) Steud., Syn. Pl. Glumac. 2: 144 (1855). $\quad$ Fig. 4g

Distribution: Argentina, Bolivia, Paraguay, Uruguay and in Brazil occurs in the Northeast, Central-West, Southeast and South regions (Guaglianone 2001; Alves et al. 2009). Found in wet, sandy soil.

Material examined: 26.X.2015, fl. and fr., V. Liesenfeld et al. 68 (UNOP).
6.2 Rhynchospora barrosiana Guagl., Darwiniana 22: 287 (1979).

Fig. $4 \mathrm{~h}$

Distribution: Paraguay, Argentina, Uruguay and in Brazil occurs in the Central-West, Southeast and South regions (Alves et al. 2009; Weber 2014). Found in wet and drained, sandy soil.

Material examined: 26.III.2016, fl. and fr., V. Liesenfeld et al. 23 (UNOP); 26.VIII.2015, fl. and fr., V. Liesenfeld et al. 56 (UNOP); 26.X.2015, fl. and fr., V. Liesenfeld et al. 63 (UNOP). 
6.3 Rhynchospora brasiliensis Boeckeler, Vidensk. Meddel. Naturhist. Foren. Kjøbenhavn 41-42: 26 (1879).

Fig. $4 \mathrm{i}$

Distribution: Colombia, Guiana, Venezuela and in Brazil occurs in the North, Northeast, Central-West, Southeast and South regions (Alves et al. 2009; Weber 2014). Found growing on slopes with rocky outcrops and in flooded areas.

Additional material examined: BRAZIL. SANTA CATARINA: Urubici, Campo dos Padres, 9.III.2006, fl. and fr., A. Zanin et al. 34597 (FLOR). PARANÁ: Tibagi, Castro-Tibagi road $5 \mathrm{~km}$ after the border, 26.I.1997, fl. and fr., H.M. Longhi-Wagner 3811 (ICN).

6.4 Rhynchospora edwalliana Boeckeler, Vidensk. Meddel. Naturhist. Foren. Kjøbenhavn 1894: 239 (1895).

Fig. $4 \mathrm{j}$

Distribution: endemic to Brazil, occurring in the Central-West, Southeast and South regions (Alves et al. 2009; Weber 2014). Found in wet, sandy soil. Material examined: 26.III.2015, fl., V. Liesenfeld et al. 19 (UNOP).

Additional material examined: BRAZIL. SANTA CATARINA: Campo Alegre, Campos do Quiriri, 4.XI.2014, fl. and fr., L.A. Funez et al. 59748 (FLOR).

6.5 Rhynchospora globosa (Kunth) Roem. \& Schult., Syst. Veg., ed. 15 bis 2: 89 (1817).

Fig. 4k-1

Distribution: From Mexico to Uruguay. In Brazil, it occurs in the North, Northeast, Central-West, Southeast and South regions (Thomas 1994; Alves et al. 2009; Araújo et al. 2012). Found in rocky outcrops and drained, sandy soil.

Material examined: 26.III.2015, fl., V. Liesenfeld et al. 04 (UNOP); 26.VIII.2015, fl., V. Liesenfeld et al. 59 (UNOP).

6.6 Rhynchospora pungens Liebm., Mexic. Halvgr.: 252 (1850).

Fig. $4 \mathrm{~m}$

Distribution: Argentina, Bolivia, Paraguay, Uruguay, Venezuela and in Brazil occurs in the Southeast and South regions (Weber 2014). Found in dry natural fields, at hilltops.

Additional material examined: BRAZIL. PARANÁ: Tibagi, Tibagi to Ventania, 12.XII.1992, fl. and fr., H. Longhi-Wagner 2520 (ICN). BRAZIL. PARANÁ: Palmas, Wildlife Refuge, 18.I.2013, fl. and fr., P. Weber et al. 57462 (FLOR).

6.7 Rhynchospora rugosa (Vahl) Gale, Rhodora 46: 275 (1944).

Fig. 4n

Distribution: From Mexico to Brazil, occurring in the North, Northeast, Central-West, Southeast and
South regions (Thomas 1994; Alves et al. 2009; Weber 2014). Found in wet, sandy soil.

Material examined: 26.III.2015, fl. and fr., V. Liesenfeld et al. 10 (UNOP).

6.8 Rhynchospora setigera (Kunth) Griseb., Fl. Brit. W. I.: 577 (1864).

Fig. 40

Distribution: Brazil, Paraguay, Argentina and Uruguay (Barros 1960). In Brazil, it occurs in the Northeast, Central-West, Southeast and South regions (Alves et al. 2009). Found in drained, sandy soil.

Material examined: 2.VI.2015, fl., V. Liesenfeld et al. 46 (UNOP); 26.VIII.2015, fl., $V$. Liesenfeld et al. 60 (UNOP).

Additional material examined: BRAZIL. PARANÁ: Guarapuava, Farm 3 capões, 16.XII.1965, fl. and fr., $R$. Reitz \& R.M. Klein 15050 (FLOR).

6.9 Rhynchospora tenuis Link, Jahrb. Gewächsk. 1(3): 76 (1820).

Fig. $4 p$

Distribution: From Mexico to Argentina (Thomas 1994). In Brazil, it occurs in the North, Northeast, Central-West, Southeast and South regions (Alves et al. 2009). Found in wet, sandy soil.

Material examined: 26.III.2015, fl. and fr., V. Liesenfeld et al. 02 (UNOP); 2.VI.2015, fl. and fr., $V$. Liesenfeld et al. 43 (UNOP); 21.I.2016, fl. and fr., V. Liesenfeld et al. 79 (UNOP).

6.10 Rhynchospora terminalis var. terminalis (Nees) Steud., Syn. Pl. Glumac. 2: 143 (1855).

Fig. 4q-r

Distribution: Bolivia and in Brazil occurs in the Northeast, Central-West, Southeast and South regions (Alves et al. 2009; Araújo et al. 2012). Found in rocky outcrops.

Material examined: 2.VI.2015, fl., V. Liesenfeld et al. 32 (UNOP); 26.VIII.2015, fl., V. Liesenfeld et al. 53 (UNOP).

6.11 Rhynchospora velutina (Kunth) Boeckeler, Vidensk. Meddel. Naturhist. Foren. Kjøbenhavn 1869: 149 (1869).

Fig. 4s Distribution: Tropical America (Thomas 1994). In Brazil, it occurs in the North, Northeast, CentralWest, Southeast and South regions (Alves et al. 2009). Found in wet, sandy soil.

Additional material examined: BRAZIL. PARANÁ: Tibagi, Guartelá State Park, 30.X.2003, fl., fr., M.R.B. do Carmo 348 (ICN). 
7. Scleria P.J.Bergius, Kongl. Vetensk. Acad. Handl. 26: 142 (1765).
Main references: Core (1936, 1952), Muniz\& Shepherd (1987), Adams (1994d) and Affonso et al. (2015).

\section{Key to the species of Scleria from Guartelá State Park}

1. Contraligule with membranous appendage; achene reticulate-verrucose ..... 7.2. Scleria leptostachya

1'. Contraligule without membranous appendage; achene smooth 7.1. Scleria distans

7.1 Scleria distans Poir. in J.B.A.M.de Lamarck, Encycl. 7: 4 (1806).

Fig. $4 \mathrm{t}$

Distribution: Pantropical (Affonso et al. 2015). In Brazil, it occurs in the North, Northeast, CentralWest, Southeast and South regions (Core 1936; Alves et al. 2009; Affonso et al. 2015). Found in damp fields.

Additional material examined: BRAZIL. RIO GRANDE DO SUL: Viamão, Itapuã State Park, 9.XII.2006, fl., fr., L. Eggers 281 (ICN).

7.2 Scleria leptostachya Kunth, Enum. P1. 2: 354 (1837).

Fig. $4 \mathrm{u}$

Distribution: South America (Affonso et al. 2015). In Brazil, it occurs in the North, Northeast, CentralWest, Southeast and South regions (Core 1936; Alves et al. 2009; Affonso et al. 2015). Found in swamps in natural fields and in sandy fields, with rocky outcrops.

Additional material examined: BRAZIL. PARANÁ: Tibagi, Guartelá State Park, 26.I.1997, fl. ad fr., H.M. Longhi-Wagner 3826 (ICN).

\section{Acknowledgments}

We are grateful to the Fundação Araucária for financial support $(51223 / 2017)$, to the Universidade Estadual do Oeste do Paraná and to the Universidade Federal de Santa Catarina for the infrastructure provided. Our gratitude also goes to the curators and technicians of the herbaria FLOR, ICN, MBM and UNOP, and to Hudson Moggioni Munhoz for the assistance elaborating the map. We also thank the Guartelá State Park team and the Instituto Ambiental do Paraná for the collecting permits and the infrastructure provided.

\section{References}

Adams CD (1994a) Cyperus L. In: Davidse G, Sousa MS \& Chater AO (eds.) Flora mesoamericana Vol. 6. Alismataceae a Cyperaceae. Missouri Botanical Garden, St. Louis. Pp. 423-440.

Adams CD (1994b) Fimbristylis Vahl. In: Davidse G, Sousa MS \& Chater AO (eds.) Flora mesoamericana
Vol. 6. Alismataceae a Cyperaceae. Missouri Botanical Garden, St. Louis. Pp. 455-457.

Adams CD (1994c) Lagenocarpus Nees. In: Davidse G, Sousa MS \& Chater AO (eds.) Flora mesoamericana Vol. 6. Alismataceae a Cyperaceae. Missouri Botanical Garden, St. Louis. Pp. 476-476.

Adams CD (1994d) Scleria P. Bergius. In: Davidse G, Sousa MS \& Chater AO Flora mesoamericana Vol. 6. Alismataceae a Cyperaceae. Missouri Botanical Garden, St. Louis. Pp. 476-485.

Affonso R, Zanin NA, Brummitt NA \& Araújo AC (2015) Diversity of Scleria (Cyperaceae) in Santa Catarina, Brazil. Rodriguésia 66: 353-367.

Aguiar TH \& Vieira AOS (2011) Florística do Parque Estadual do Cerrado de Jaguariaíva - Paraná: atualização da lista de espécies. In: Carpanezzi OTB \& Campos JB (orgs.) Coletânea de pesquisas: Parques Estaduais de Vila Velha, Cerrado e Guartelá. Instituto Ambiental do Paraná, Curitiba. Pp. 263-272.

Alves M, Araújo AC, Prata AP, Vitta F, Hefler S, Trevisan R, Gil ASB, Martins S \& Thomas W (2009) Diversity of Cyperaceae in Brazil. Rodriguésia 60: 771-782.

Alves M, Trovó M, Forzza RC \& Viana P (2015) Overview of the systematics and diversity of Poales in the Neotropics with emphasis on the Brazilian flora. Rodriguésia 66: 305-328.

Araújo AC (2001) Revisão taxonômica de Rhynchospora Vahl sect. Pluriflorae Kük.(Cyperaceae). Tese de Doutorado. Universidade de São Paulo, São Paulo. 372p.

Araújo AC \& Longhi-Wagner HM (1996) Levantamento taxonômico de Cyperus L. subg. Anosporum (Nees) C.B. Clarke (Cyperaceae - Cypereae) no Rio Grande do Sul, Brasil. Acta Botanica Brasilica 10: 153-192.

Araújo AC, Longhi-Wagner HM \& Thomas WW (2012) A synopsis of Rhynchospora sect. Pluriflorae (Cyperaceae). Brittonia 64: 381-393.

Ardissone RE (2013) Sinopse taxonômica de Bulbostylis Kunth (Cyperaceae) para a Região Sul do Brasil. Dissertação de Mestrado. Universidade Federal de Santa Catarina, Florianópolis. 118p.

Barros M (1960) Las ciperáceas del estado de Santa Catalina. Sellowia 12: 181-448.

BFG - The Brazil Flora Group (2018) Brazilian Flora 2020: innovation and collaboration to meet Target 
1 of the Global Strategy for Plant Conservation (GSPC). Rodriguésia 69: 1513-1527. DOI: 10.1590/2175-7860201869402

Bridson D \& Forman L (2004) The herbarium handbook. The Royal Botanic Garden, Kew. 346p.

Carmo MRB, Andrade ALP, Santos GASD \& Assis MA (2012) Análise estrutural em relictos de Cerrado no Parque Estadual do Guartelá, município de Tibagi, estado do Paraná, Brasil. Ciência Florestal 22: 505-517.

Carmo MRB \& Assis MA (2012) Caracterização florística e estrutural das florestas naturalmente fragmentadas no Parque Estadual do Guartelá, município de Tibagi, estado do Paraná. Acta Botanica Brasilica 26: 133-145.

Carmo MRB (2006) Caracterização fitofisionômica do Parque Estadual do Guartelá, município de Tibagi, estado do Paraná. Tese de Doutorado. Universidade Estudal Paulista "Julio de Mesquita Filho", Rio Claro. 142p.

Core EL (1936) The American species of Scleria. Brittonia 2: 1-105.

Core EL (1952) The genus Scleria in Brazil. Rodriguésia 15: 137-162.

Ferreira PMA \& Eggers L (2008) Espécies de Cyperaceae do Centro de Pesquisa e Conservação da Natureza Pró-Mata, município de São Francisco de Paula, Rio Grande do Sul, Brasil. Acta Botanica Brasilica 22: 173-185.

Ferreira AP \& Maranho LT (2011) Avaliação da sucessão ecológica da Estepe Gramíneo - Lenhosa pouco alterada após fogo controlado e roçada no Parque Estadual Vila Velha, PR, Brasil. In: Carpanezzi OTB \& Campos JB (orgs.) Coletânea de pesquisas: Parques Estaduais de Vila Velha, Cerrado e Guartelá. Instituto Ambiental do Paraná, Curitiba. Pp. 36-45.

Filgueiras TS, Brochado AL, Nogueira PE \& Guala II G F (1994) Caminhamento - um método expedito para levantamentos florísticos qualitativos. Cadernos de Geociências 2: 39-43.

Freitas DB, Miyamoto SNA \& Carmo MRB (2011) Análise estrutural de um Campo Limpo em regeneração após duas décadas de uso agrícola no Parque Estadual de Vila Velha, Ponta Grossa, PR. In: Carpanezzi OTB \& Campos JB (orgs.) Coletânea de pesquisas: Parques Estaduais de Vila Velha, Cerrado e Guartelá. Instituto Ambiental do Paraná, Curitiba. Pp. 62-66.

Gil ASB \& Bove CP (2004) Eleocharis R. Br. (Cyperaceae) no estado do Rio de Janeiro, Brasil. Biota Neotropica 7: 163-193.

Govaerts R, Koopman J, Simpson D, Goetghebeur P, Wilson K, Egorova T \& Bruhl J (2011) World checklist of Cyperaceae. Available at $<$ http://apps. kew.org/wcsp/incfamilies.do $>$. Acessed on 14 October 2016.
Govaerts R, Simpson D, Bruhl J, Egorova T, Goetghebeur P \& Wilson K (2007) World checklist of Cyperaceae - Sedges. Kew Gardens, Surrey. 765p.

Guaglianone ER (1980) Contribución al estudio del gênero Rhynchospora Vahl (Cyperaceae) II. Darwiniana 22: 499-509.

Guaglianone ER (1981) Contribución al estudio del género Rhynchospora Vahl (Cyperaceae) III. Darwiniana 23: 489-506.

Guaglianone ER (1982) Contribución al estudio del género Rhynchospora Vahl (Cyperaceae) IV. $R$. iberae nueva especie de América Austral. Darwiniana 24: 4469-473.

Guaglianone ER (2001) Contribución al estudio del género Rhynchospora (Cyperaceae) V. Sección Longirostres en América Austral. Darwiniana 39: 287-342.

Guaglianone ER \&. Moore G (2001) Identidad de dos especies sudamericanas de Rhynchospora (Cyperaceae): $R$. rostrata y $R$. organensis. Darwiniana 39: 239-246.

Hefler SM \& Longhi-Wagner HM (2012) Cyperus L. subg. Cyperus (Cyperaceae) na Região Sul do Brasil. Revista Brasileira de Biociências 10: 327-372.

Instituto Ambiental do Paraná (2002) Plano de manejo do Parque Estadual do Guartelá. Instituto Ambiental do Paraná, Curitiba. 309p.

Koyama T (1972) Cyperaceae - Rhynchosporeae and Cladieae Memoirs of the New York Botanical Garden 23: 23-89.

Labiak PH (2014) Aspectos fitogeográficos do Paraná. In: Kaehler M, Goldenberg R, Evangelista PHL, Ribas OS, Vieira AOS \& Hatschbach GG (eds.) Plantas vasculares do Paraná. Universidade Federal do Paraná, Curitiba. Pp. 7-22.

López MG \& Simpson DA (2012) The Bulbostylis capillaris complex (Cyperaceae) in southern South America. Kew Bulletin 67: 225-234.

Lorenzi H (2014) Manual de identificação e controle de plantas daninhas - plantio direto e concencional. $7^{\mathrm{a}}$ ed. Instituto Plantarum, São Paulo. 383p.

Maack R (2012) Geografia física do estado do Paraná. $4^{\mathrm{a}}$ ed. UEPG, Ponta Grossa. 526p.

Maia FR \& Goldenberg R (2014) Melastomataceae from the "Parque Estadual do Guartelá", Tibagi, Paraná, Brazil: species list and field guide. Journal of Species Lists and Distribution 10: 1316-1323.

Martins S, Alves M \& Scatena V (2015) Occurrence and evolutionary inferences about Kranz anatomy in Cyperaceae (Poales). Anais da Academia Brasileira de Ciências 87: 2177-2188.

Michelan VS, Trevisan R, Silva CRM, Souza RF, Luceño M \& Vanzela ALL (2012) Morphological and genomic characterization of Rhynchospora tenuis complex (Cyperaceae) and its taxonomic implications. Rodriguésia 63: 775-784. 
Michelon C \& Labiak PH (2013) Samambaias e Licófitas do Parque Estadual do Guartelá, PR, Brasil. Hoehnea 40: 191-204.

Muniz C \& Shepherd J (1987) O gênero Scleria Berg. (Cyperaceae) no estado de São Paulo. Revista Brasileira de Botânica 10: 63-94.

Oliveira MB \& Maranho LT (2011) Efeitos do fogo controlado e do roçado sobre a sucessão ecológica da Estepe Gramineo-Lenhosa no Parque Estadual de Vila Velha, PR, Brasil, em área com avanço de vassoura (Bacharis spp.). In: Carpanezzi OTB \& Campos JB (orgs.) Coletânea de pesquisas: Parques Estaduais de Vila Velha, Cerrado e Guartelá. Instituto Ambiental do Paraná, Curitiba. Pp. 46-55.

Oliveira E, Putrique M, Ribas DC \& Panizon M (2011) Monitoramento de Sus scrofa (Mammalia, Suidae) no Parque Estadual de Vila Velha, Paraná, Brasil. In: Carpanezzi OTB \& Campos JB (orgs.) Coletânea de pesquisas: Parques Estaduais de Vila Velha, Cerrado e Guartelá. Instituto Ambiental do Paraná, Curitiba. Pp. 85-93.

Pedersen TM (1972) Cyperus laetus Presl and Cyperus rigens Presl, two badly understood South American sedges, with notes on some related species. Darwiniana 17: 527-547.

PrataAP (2004) O gênero Bulbostylis Kunth (Cyperaceae) no Brasil. Tese de Doutorado. Universidade de São Paulo, São Paulo. 197p.

Rocha EA \& Luceño M (2002) Estudo taxonômico de Rhynchospora Vahl Seção Tenues (Cyperaceae) no Brasil. Hoehnea 29: 189-214.

Ronchi HN (2015) Estudo taxonômico de Fimbristylis Vahl (Cyperaceae) para Santa Catarina e do complexo F. dichotoma (L.) Vahl para o Sul do Brasil. Dissertação de Mestrado. Universidade Federal de Santa Catarina, Florianópolis. 156p.

Silva AR, Andrade ALP, Velazco SE, Galvão F \& Carmo MRB (2016) Florística e fitossociologia em três diferentes fitofisionomias campestres no Sul do Brasil. Hoehnea 43: 325-347.

Thomas WW (1994) Rhynchospora Vahl. In: Davidse G, Sousa MS \& Chater AO (eds.) Flora mesoamericana Vol. 6. Alismataceae a Cyperaceae. Missouri Botanical Garden, St. Louis. Pp. 404-422.

Trevisan R \& Boldrini II (2008) O gênero Eleocharis R. Br. (Cyperaceae) no Rio Grande do Sul, Brasil. Revista Brasileira de Biociências 6: 7-67.

Trevisan R, Ferreira PMA \& Boldrini II (2008) A família Cyperaceae no Parque Estadual de Itapuã, Viamão, Rio Grande do Sul, Brasil. Revista Brasileira de Biociências 6: 217-244.

Tucker GC (1994) Revision of the Mexican species of Cyperus (Cyperaceae). Systematic Botany Monographs 43: 1-186.

Vasconcellos GC \& Rocha MRL (2011) A importância dos Parques Estaduais de Vila Velha, Guartelá e Cerrado na produção e divulgação de conhecimento científico. In: Carpanezzi OTB \& Campos JB (orgs.) Coletânea de pesquisas: Parques Estaduais de Vila Velha, Cerrado e Guartelá. Instituto Ambiental do Paraná, Curitiba. Pp. 7-8.

Veloso HP, Filho ALRR \& Lima JCA (1991) Classificação da vegetação brasileira, adaptada a um sistema universal. Fundação Instituto Brasileiro de Geografia e Estatística, Rio de Janeiro. 124p.

Vitta FA (2005) Revisão taxonômica e estudos morfológicos e biossistemáticos em Cryptangium Schrad. ex Nees e Lagenocarpus Nees (Cyperaceae: Cryptangieae). Tese de Doutorado. Universidade Federal do Rio Grande do Sul, Porto Alegre. 225p.

Weber PAP (2014) Revisão taxonômica de Rhynchospora Vahl Seção Glaucae C.B. Clarke (Cyperaceae) para a América do Sul. Dissertação de Mestrado. Universidade Federal de Santa Catarina, Florianópolis. 120p. 